RECEBIDO EM 03/10/2012. ACEITO EM 24/03/2014.

\title{
Modelo de König para medir a satisfação e fidelização dos clientes através da logística reversa de pós-venda: Aplicação em uma concessionária de veículos em Joinville/SC
}

\section{Tatiana Cunha König}

Instituto Superir Tupy - IST/SOCIESC

tatikonig@hotmail.com

\author{
Patrícia Costa Duarte \\ Professora da Universidade Federal de Pelotas-UFPel \\ Curso de Engenharia de Produção \\ pcduarte_rs@yahoo.com.br
}

\section{RESUMO}

Este artigo tem como objetivo apresentar o modelo de satisfação desenvolvido por König (2012), adaptado do modelo ACSI, que pretendeu, através de práticas da logística reversa pós-venda aplicados em uma concessionária de veículos em Joinville/SC, contribuir na busca pela fidelização de clientes. A intenção deste modelo é medir se o construto "logística reversa de pós-venda", através de seus serviços, juntamente com as demais variáveis, contribuem na conquista da satisfação e fidelização dos clientes compradores de automóveis. O modelo foi aplicado em clientes de uma concessionária de veículos franceses, revendedora de carros importados e nacionais. A escolha por essa concessionária de automóveis ocorreu por seus produtos serem destinados a atender um público alvo com um nível elevado de exigência. Como resultado da pesquisa, foi possível identificar que os clientes da concessionária percebem na logística reversa de pós-venda um diferencial para eliminar a reclamação e assim, tornar-se satisfeitos e fidelizados a marca.

Palavras-chave: Satisfação dos clientes, Logística reversa, Setor automobilístico.

\begin{abstract}
This article aims to present the model of customer satisfaction developed by König (2012) and adapted the model ACSI, which sought, through the practices of reverse logistics aftermarket applied at a car dealership in Joinville/SC, contribute to the quest for customer loyalty. The intent of this model is to measure the construct "reverse logistics after sales" through its services, along with other variables, contribute to the achievement of customer satisfaction and loyalty car buyers. The model was applied to clients of a French car dealership, retailer of imported and domestic cars. The choice for this car dealership occurred because their products are designed to meet a target audience with a high level of demand. As a result of the research, it was possible to identify the dealership that customers perceive the reverse logistics of aftermarket differential to eliminate the complaint and thus become satisfied and loyal to the brand.
\end{abstract}

Key-words: Customer Satisfaction, Reverse Logistics, Automotive Industry. 


\section{Introdução}

A realidade do mercado sofre constantes mudanças e as empresas para se manterem ativas, devem aumentar suas responsabilidades perante os seus consumidores, os seus concorrentes e, principalmente, na satisfação de seus clientes. Atualmente, observa-se uma dinâmica na oferta de produtos e serviços aonde os mesmos vão se aprimorando e incorporando novas tecnologias numa constante rapidez (GUARNIERI et al., 2006). De um lado, esta crescente competição global traz benefícios aos clientes, que por sua vez, estão mais exigentes e difíceis de agradar, mas do outro ponto de vista, dificulta as empresas a manter esses clientes fiéis (KOTLER, 2003). Tendo em vista que a intenção prioritária das organizações é o aumento de sua lucratividade, ao utilizar recursos confiáveis e que garantam a qualidade do seu serviço ou produto, tornam fator primordial para a fidelização e satisfação do seu consumidor.

Segundo Cardoso (2012), conquistar a fidelidade do cliente é, cada vez mais, o desafio de empresas e profissionais preocupados não só com a sua competitividade, mas com sua própria sobrevivência no mercado. Conseguir fidelizar os consumidores é quase que uma garantia de sobrevivência e bom funcionamento para qualquer empresa, considerando que os clientes fiéis são os mais rentáveis.

Pensando em não perder esses valiosos clientes para a concorrência, as empresas estão buscando meios e ferramentas que se destacam na elaboração de vantagens competitivas para manter os clientes e torná-los fiéis. Autores como Leite (2003) e Figueiredo et al. (2006), acreditam que as empresas modernas utilizam-se da logística reversa, como forma de ganho de competitividade no mercado com foco no cliente e, ainda que ao utilizar os serviços da logística reversa como sendo uma ferramenta competitiva, as empresas poderiam bloquear a entrada de novos concorrentes e com isso, manter a concorrência afastada.

Sabemos que a logística reversa está associada à destinação de bens após seu consumo, mas não acaba por aí. A logística reversa pode ir além, sendo um componente potencial no que se refere aos serviços de pós-venda, no aprimoramento da satisfação e fidelização de clientes, agregando valor ao produto e aumentando a rentabilidade da empresa gerando assim uma vantagem competitiva frente aos concorrentes (COTTRILL, 2000).

Permanecendo nos conceitos de Figueiredo et al. (2006), para o mundo dos negócios é fundamental manter um bom relacionamento com os clientes. Através da manutenção da carteira de clientes fiéis, as empresas podem diminuir a dependência de estar constantemente buscando novos clientes, numa luta com um número cada vez maior de concorrentes. Ainda os mesmos autores afirmam que a acirrada perseguição a novos clientes acaba custando mais caro para as empresas do que administrar os clientes atuais tornando-os fiéis.

O mercado automobilístico no Brasil por vários anos vem se mantendo aquecido (FENABRAVE, 2010). As diversas concessionárias existentes no mercado buscam, através de pesquisas, melhorias nos serviços ao clientes no intuito de criar um relacionamento duradouro e fiel. Levando em consideração que a satisfação e fidelização de clientes é uma maneira que as empresas do setor automobilístico têm em permanecer vivas no mercado, conforme Whiteley (1996) afirma, satisfazer o cliente é crucial para uma empresa, não apenas para o sucesso, mas até para a sua sobrevivência. Pesquisas de satisfação e fidelização de clientes devem ser efetuadas com frequência na intenção de ouvir o que os clientes têm a dizer, absorver essa informação, e assim, adaptar serviços que contribuem para o alcance da satisfação e fidelização dos mesmos.

Em meio às vastas possibilidades existentes de marcas a disposição dos clientes, a fonte de diferenciação para fidelizá-los pode estar nos serviços logísticos reversos de pós-venda. Diante dessa conjuntura, este artigo tem como objetivo apresentar o modelo de satisfação e fidelização de clientes desenvolvido por König (2012) que pretendeu através de práticas da logística reversa de pós-venda aplicados em uma concessionária de veículos em Joinville, SC, contribuir na busca pela fidelização de clientes. 


\section{Modelos de satisfação e fidelização de clientes}

Neste capítulo serão abordados alguns modelos de satisfação e fidelização de clientes já existes. Segundo Johnson et al. (2001), os modelos de satisfação e fidelização definem de uma maneira geral a satisfação dos clientes como um todo ou a evolução acumulada das experiências de compra adquirida, podendo ser utilizada por empresas de serviços, órgãos públicos e indústrias.

\subsection{Modelo Sueco (SCSB)}

O modelo Sueco, conhecido como SCSB - Swedish Customer Satisfaction Index, conforme Fornell (1992 apud RODRIGUES, 2003), contempla dois fatores antecedentes a satisfação que são: o desempenho percebido e a expectativa do cliente, conforme detalhado na Figura 1.

O desempenho percebido é a performance percebida pelo cliente com o produto ou serviço adquirido, ou seja, o valor percebido em relação ao preço pago (Johnson et al., 2001). Ao adquirir determinado produto ou serviço, o cliente estará interessado em comparar marcas e categorias semelhantes com o valor investido nessa aquisição.

O outro fator que antecede a satisfação no modelo Sueco, a expectativa do cliente, consiste na relação ao desempenho de um produto ou serviço oferecido. Enquanto o desempenho percebido captura as experiências mais recentes, a expectativa do cliente captura uma experiência de consumo anterior de um cliente com os produtos ou serviços de uma empresa (JOHNSON et al., 2001).

O mesmo autor afirma ainda que as consequências da satisfação deste modelo são derivados da teoria exit-voice (saída-voz), na qual são descritas situações em que o cliente torna-se insatisfeito com o produto ou serviço oferecido pela empresa e a empresa descobre sua falha através de dois feedbacks, deixa de comprar (exit) ou via reclamações (voice) para receber restituição. Assim, as conseqüências imediatas para aumentar a satisfação são diminuir as reclamações e aumentar a fidelidade do cliente.

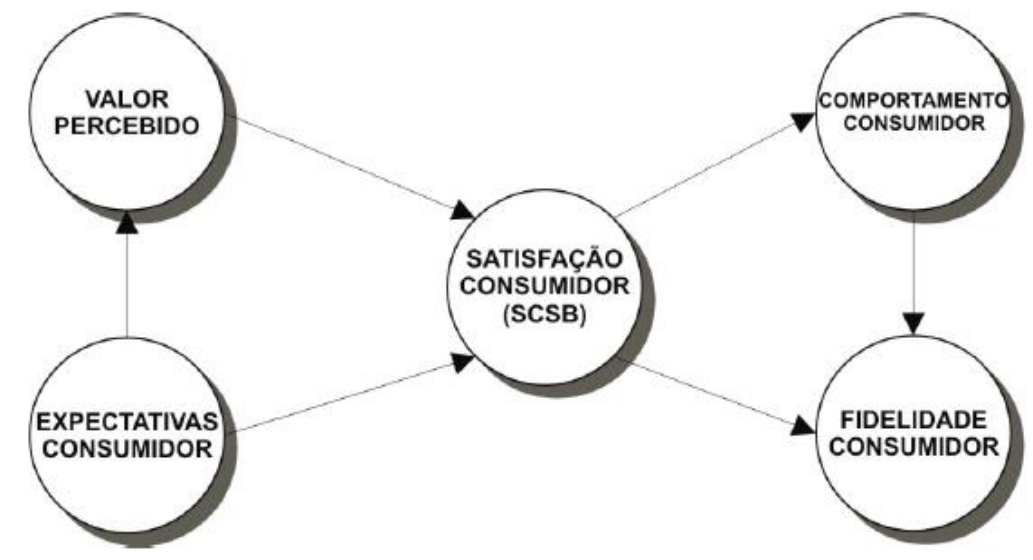

Figura 1 - Modelo Sueco

Fonte: Johnson et. al. (2001 apud Rodrigues, 2003)

\subsection{Modelo Europeu (ECSI)}

No modelo ECSI - European Customer Satisfaction Index, o que se destaca é a possibilidade existente de ser aplicado para diferentes tipos de empresas pertencentes a diferentes setores (FORNELL, 1992 apud RODRIGUES, 2003).

Para Johnson et al. (2001) os construtos expectativas do consumidor, qualidade percebida, valor percebido, satisfação e fidelização do consumidor são modelados da mesma forma que o modelo ACSI, como também a distinção entre serviço de qualidade e produto de qualidade, conforme apresentado na Figura 2. 


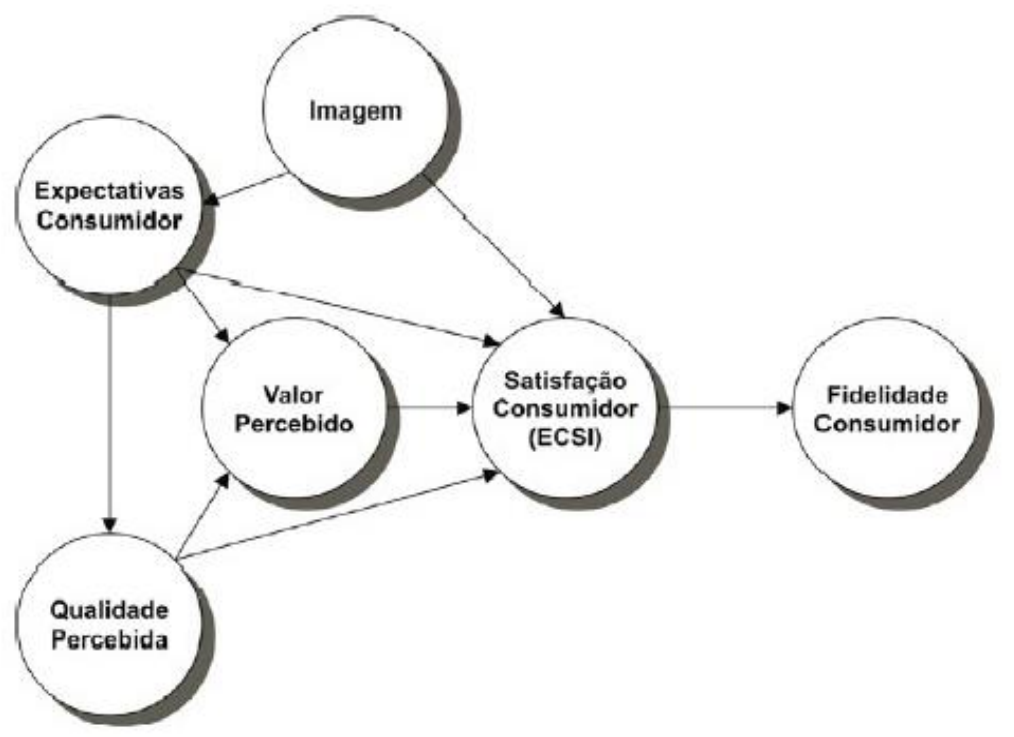

Figura 2 - Modelo Europeu

Fonte: Johnson et. al. (2001)

Apesar de parecerem semelhantes o modelo americano e europeu, existe duas fundamentais diferenças entre eles. Primeiro, o modelo europeu não inclui o construto de reclamações dos consumidores como uma consequência da satisfação. Segundo, é incluído o construto imagem da empresa como sendo uma variável, em que ela é especificada para efeito direto nas expectativas do consumidor e satisfação. O objetivo do modelo europeu era desenvolver um instrumento de mensuração da satisfação mais adequado ao mercado europeu (JOHNSON et al., 2001).

\subsection{Modelo Norueguês (NCSB)}

O primeiro modelo norueguês (NCSB) foi desenvolvido em 1996, e era idêntico ao modelo americano, apenas com a exceção da inclusão do construto imagem da empresa com o intuito de conseguir a satisfação e fidelização dos clientes (JOHNSON et al., 2001).

$\mathrm{O}$ mesmo autor afirma posteriormente que o construto imagem foi adicionado ao modelo, porque alguns estudiosos perceberam o forte relacionamento existente entre a intenção e a atitude de compra dos clientes com a imagem da empresa, conforme ilustrada na Figura 3. A chave para a percepção da imagem de determinada empresa é a associação do relacionamento organizacional guardada na memória do consumidor.

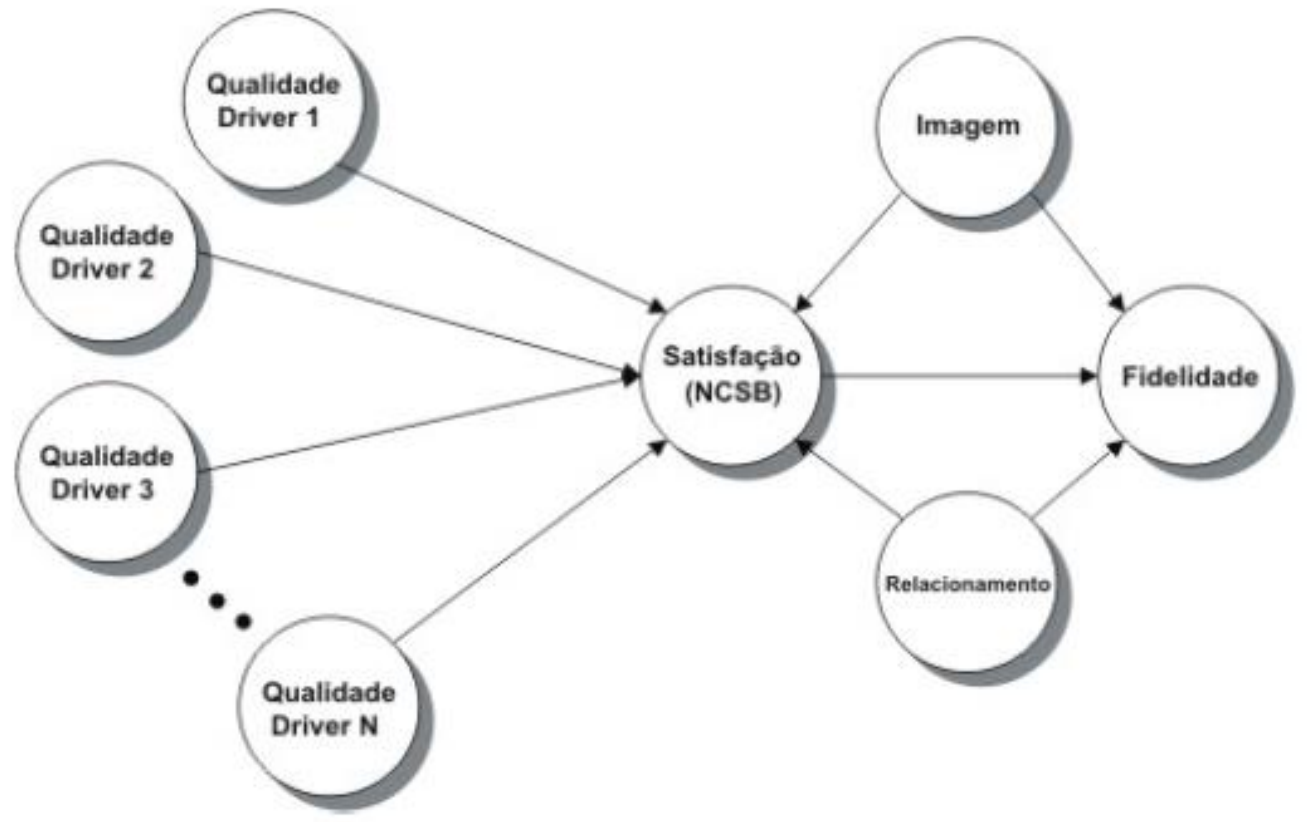


De acordo com o desenvolvimento do marketing, de uma evolução transacional para uma orientação relacional entre serviços providos, o modelo norueguês foi expandido ao longo do tempo a fim de incluir os construtos relacionados com a inclusão da variável relacionamento chamada de compromisso que se dividem em compromisso afetivo e compromisso acumulado. Os construtos compromissos são modelados mediante os efeitos da satisfação na fidelidade (JOHNSON et al., 2001 apud LIRA, 2003).

\subsection{Modelo Americano (ACSI)}

Este modelo ACSI - American Customer Satisfaction Index foi desenvolvido em 1994 pela University of Michigan Business School, sendo utilizadas as especificações do modelo Sueco como base de sua criação.

Segundo Johnson et al. (2001 apud RODRIGUES, 2003), as principais diferenças entre o modelo sueco e o modelo americano são as adições da qualidade percebida, distinta do valor percebido, e a implementação das medições das expectativas do consumidor, conforme mostra a Figura 4.

O modelo americano é explicado minuciosamente, considerando que este serviu como base para o desenvolvimento do modelo de König (2012), pois diferente dos demais modelos anteriormente apresentados, este traz o construto de reclamação do consumidor como consequente da satisfação, um fator relevante para o alcance da fidelização dos clientes. Observa-se no modelo os seguintes construtos:

- qualidade percebida: é a avaliação do mercado servido de recente experiência de consumo e, espera-se ter um efeito direto e positivo sobre a satisfação do cliente;

- valor percebido: é o nível percebido de qualidade do produto em relação ao preço pago pelo cliente;

- expectativas do consumidor: é uma medida influenciada pela experiência de consumo anterior;

- satisfação do consumidor: esta se encontra no centro modelo, tendo como antecedentes a qualidade percebida, a expectativa do consumidor e o valor percebido e, como consequentes a reclamação e fidelidade do consumidor. Todos esses antecedentes e consequentes passam pela satisfação;

- reclamação do consumidor: é o sistema de serviço oferecido ao cliente bem como a solução dada pelo fornecedor;

- fidelidade do consumidor: a solução passada ao cliente positivamente, esse se torna fiel (FORNELL, 1996 apud RODRIGUES, 2003).

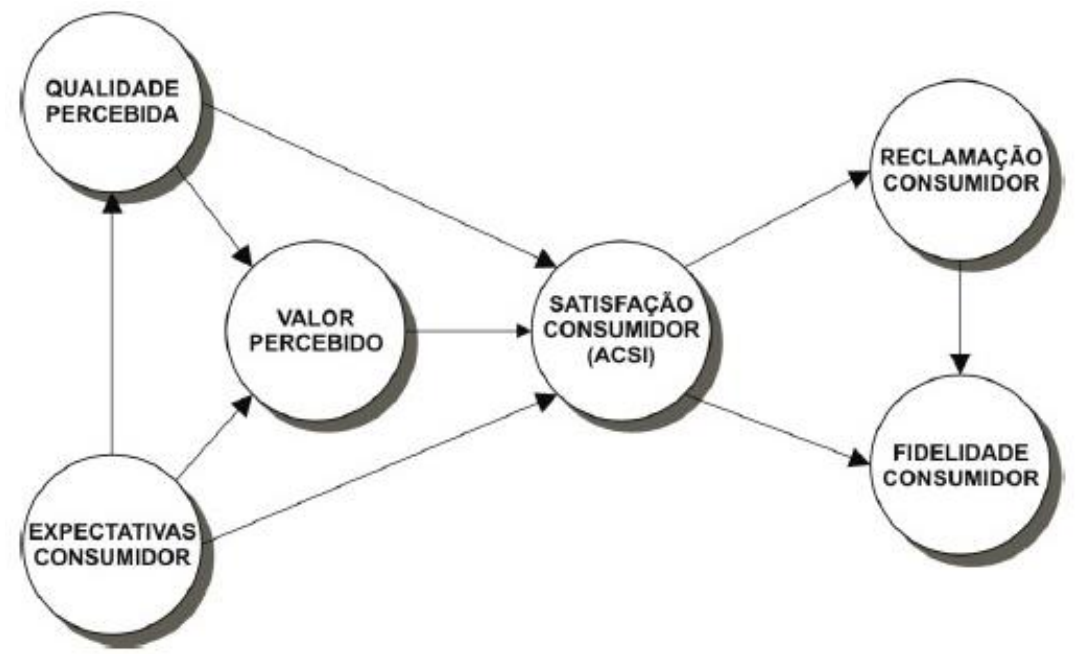

Figura 4 - Modelo Americano

Fonte: Johnson et. al. (2001) 


\section{Logística reversa}

Quando o assunto é logística pensa-se em todo o processo do produto de seu ponto de partida até seu ponto de consumo. No entanto, existe também todo um fluxo reverso que necessita ser administrado, ou seja, o acompanhamento do processo de um produto ou serviço do ponto do consumidor final, no caso o cliente, até a cadeia de suprimentos, conforme mostra a Figura 5.

Rogers e Tibben $(1998$, p. 95) explicam que "a logística reversa é conhecida como sendo a responsável pela movimentação de produtos através de canais reversos de distribuição. Logo, logística reversa é um processo de planejamento, implementação e controle de matérias primas, estoque em processo, produtos acabados e informações relacionadas a partir do ponto do consumidor para o local de origem". Tendo a missão de dispor as mercadorias ou serviços em condições desejadas, no lugar certo e no tempo certo, fornecendo assim competitividade às empresas (BALLOU, 2006).

A logística reversa cuida dos materiais que se iniciam nos pontos de consumo dos produtos e terminam nos pontos de origem, com o objetivo de recapturar valor ou disposição final (NOVAES, 2007). Logo, podemos dizer que a vida de um produto, do ponto de vista logístico, não finaliza com sua entrega ao cliente. Produtos têm seu ciclo de vida onde se tornam obsoletos, danificados, não funcionam e, devem retornar ao seu ponto de origem para serem adequadamente descartados, reparados ou reaproveitados, sendo nesse momento que a logística reversa atua.

Ter o foco na satisfação dos clientes obriga as empresas a terem a capacidade de gerenciar o retorno dos produtos, de acordo com a sua causa, que esse se dá por vários motivos: por ser um produto defeituoso, ou por ser um produto fora das especificações do consumidor, ou um simples descarte de um produto já utilizado. E assim, dentro desse contexto que a logística reversa teve início (LACERDA, 2009).

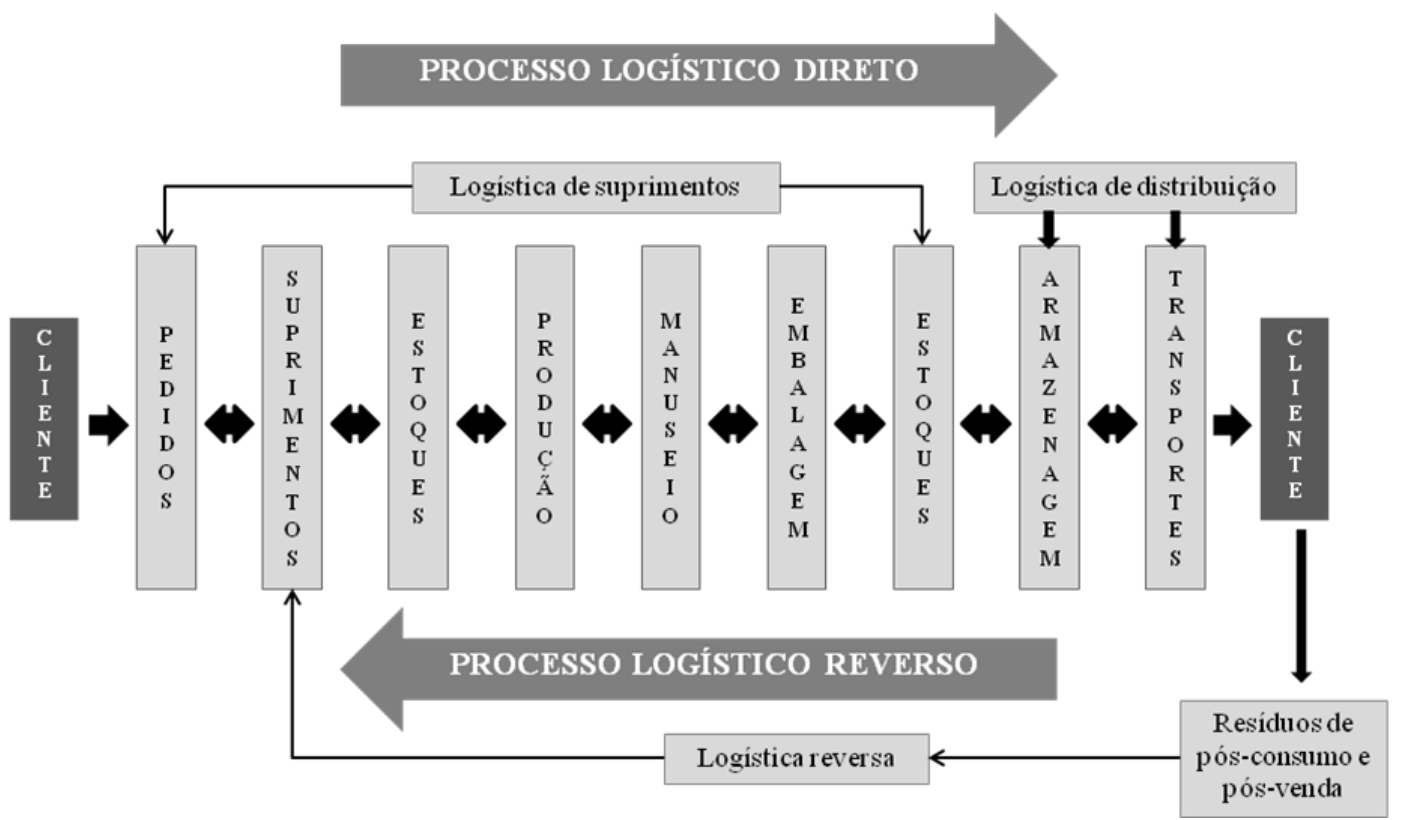

Figura 5 - Gerenciamento da cadeia de suprimentos direta $\mathrm{X}$ reversa

Fonte: Rogers e Tibben (1998)

Para Leite (2003) a logística reversa é pouco estudada e o motivo se dá a pouca importância econômica quando comparada com os fluxos de distribuição diretos. Mas, alguns fatores como: velocidade de lançamento de produtos, o ágil crescimento da tecnologia e da informação, a busca da competitividade, a conscientização ecológica, a produção de matéria prima secundária e a preocupação com a satisfação dos clientes estão modificando as relações do mercado em geral e, justificando as preocupações estratégicas das empresas, do governo e da sociedade com relação aos canais de distribuições reversos. 
Dentro dos canais de distribuição reversos existem duas categorias onde apresentam características e objetivos distintos. São eles: logística reversa de pós-consumo e logística reversa de pós-venda (LEITE, 2003).

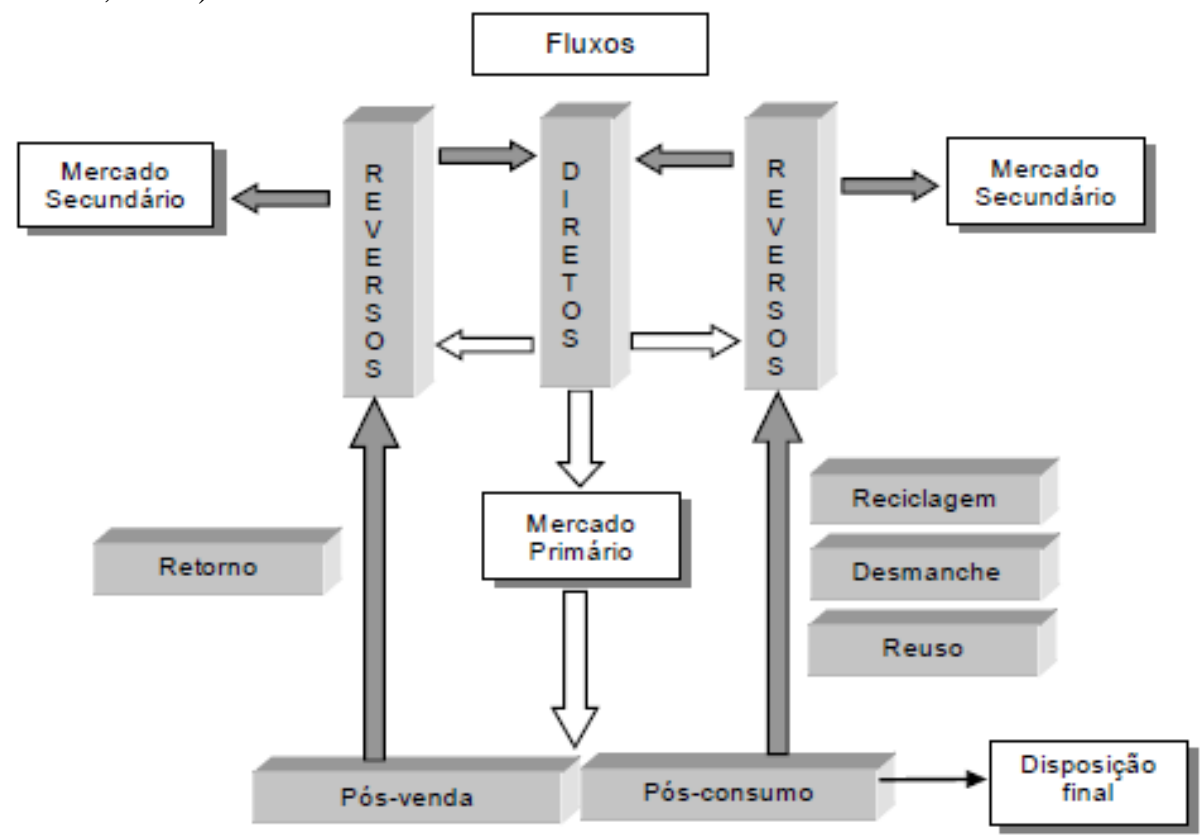

Figura 6 - Canais de distribuição diretos e reversos

Fonte: Leite (2003, p. 5)

Os canais de distribuição reversos de pós-consumo, conforme vistos na Figura 6 são responsáveis pelo fluxo reverso de produtos e de materiais originados no descarte dos produtos após sua utilidade e que retornam ao ciclo produtivo através de reciclagem ou reuso. O canal de distribuição reverso de pós-venda é responsável pelo retorno dos produtos que apresentam problemas relacionados à qualidade em geral ou a processos comerciais entre empresas. Por ser o principal propósito deste artigo, o canal de distribuição reverso de pós-venda será descrito minuciosamente no próximo item.

\subsection{Logística reversa de pós-venda}

Um produto ao utilizar o canal de distribuição reverso de pós-venda, apresentou particularidades, tendo como suas principais razões o término da validade, o estoque excessivo no canal de distribuição, e por apresentar problemas de qualidade e defeito de fabricação, entre outros. Esses produtos utilizam o canal reverso de pós-vendas para serem devolvidos aos fabricantes ou distribuidores e é nesse momento que se determina o destino que se dará a esse produto, podendo ser encaminhado ao mercado secundário, pode ser encaminhado para o conserto ou até mesmo para o desmanche (LEITE, 2003).

Segundo Drohomeretski e Suetake (2008) a classificação da logística reversa de pós-venda, é caracterizada por processos de comercialização entre os participantes do canal reverso. Leite (2003) defende que o objetivo da logística reversa de pós-venda está em agregar valor a um produto devolvido por razões comerciais, por erros no processamento dos pedidos, por garantia dada pelo fabricante, por defeitos ou falhas de funcionamento, avarias de transporte, entre outros.

São muitos os caminhos diferentes da logística reversa de pós-venda, que precisam ser examinados e destinados a um canal reverso de melhor acréscimo ou valor pretendido pelas organizações responsáveis por esses (LEITE, 2003). Ainda o mesmo autor, informa que a logística reversa de pós-venda deve planejar, operar e controlar o fluxo de retorno dos produtos de pós-venda que são devolvidos por diversos motivos. A Figura 7 detalha os diversos motivos de retorno dessa categoria.

O retorno de pós-vendas acontece devido a três motivos que são conhecidos como problemas comerciais, problemas de garantia ou qualidade e problemas de substituição de componentes (LEITE, 2003). Dentro da categoria retornos comerciais encontra-se duas subdivisões: os retornos contratuais e 
os retornos não contratuais. Neles são envolvidos os movimentos logísticos reversos de mercadorias devolvidas por erros de expedição, excesso de estoque, liquidação de estação de vendas entre outros, onde serão retornadas ao ciclo de negócios por meio de redistribuição em outros canais de vendas. $\mathrm{Na}$ categoria de retorno por garantia/qualidade se enquadram os produtos que apresentam defeitos de fabricação ou de funcionamento. Esses produtos sofrerão consertos onde será permitido que retornem ao mercado primário ou secundário, agregando-o valor comercial novamente. Caso o conserto não seja possível, esses produtos são destinados ao desmanche, como os produtos de pós-consumo. Pode-se considerar ainda dentro dessa categoria a classificação de validade, que são o retorno de todos os produtos que após o termino da validade ou problemas apresentados após a venda, são devolvidos a fim de se diferenciar no serviço ao cliente. Nessa categoria, é possível citar o exemplo do recall, onde o produto devolvido, independentemente do motivo, deve ter seu valor recuperado e um tratamento adequado para não trazer perdas à empresa (Guarnieri et al., 2006). A categoria de devoluções por motivo de substituição de componentes se faz devido à substituição de componentes de bens duráveis e semiduráveis em manutenção e consertos ao longo de sua vida útil, entrando nos canais reversos de remanufaturados e com isso, voltam ao mercado primário ou secundário. Na impossibilidade de reaproveitamento esses produtos são enviados a reciclagem ou para uma disposição final. No ramo automobilístico encontram-se diversos exemplos de canais de produtos remanufaturados originados de manutenção e consertos de veículos (LEITE, 2003).

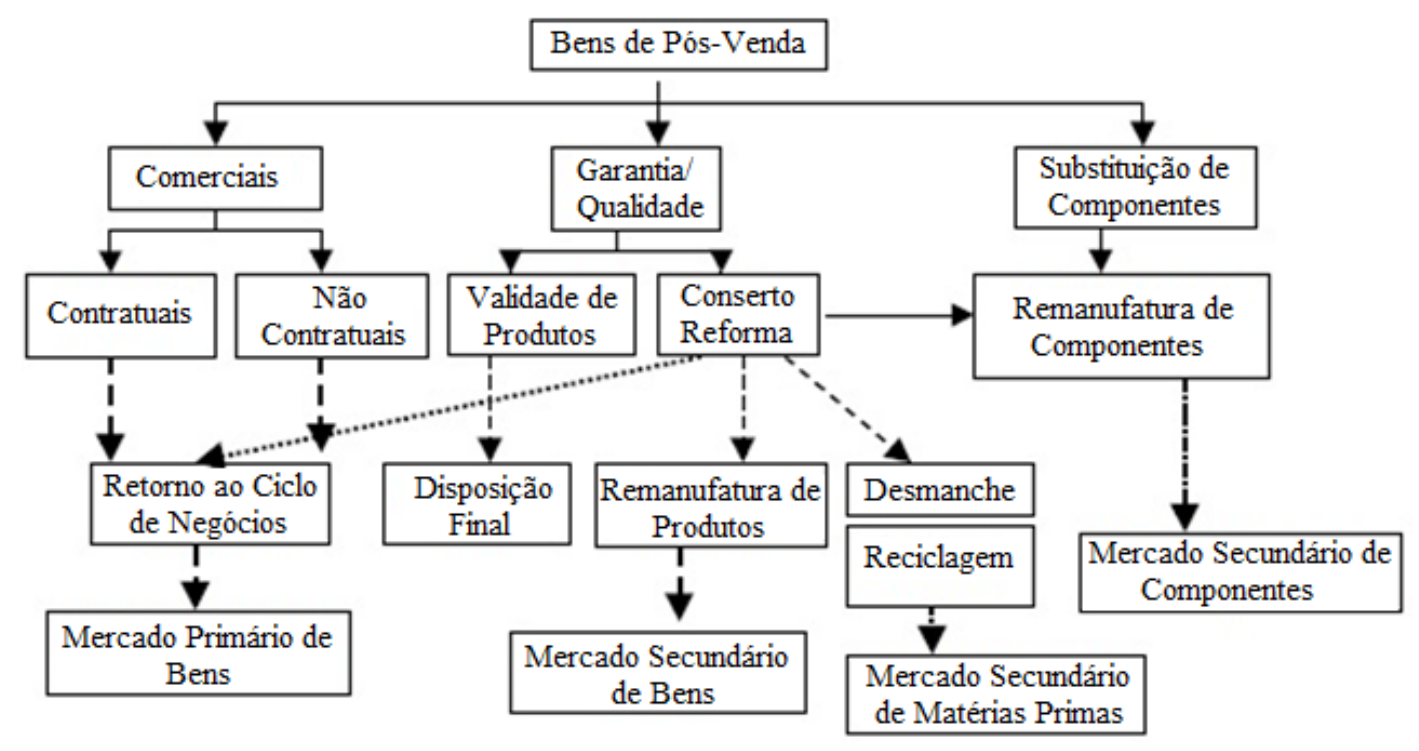

Figura 7 - Categorias de retorno de pós-venda

Fonte: Leite (2003, p. 211)

Rogers e Tibben (1998) informam que dentre os três motivos de retornos conhecidos, os que estão considerados como os principais são os problemas de garantia ou qualidade e a problemas comerciais. Na Tabela 1 são encontrados os principais exemplos de motivos que originam o retorno dos bens de pós-venda.

Tabela 1 - Principais motivos de retorno

\begin{tabular}{|l|l|}
\hline Retornos Comerciais & Exemplos de Motivos de Retornos \\
\hline Retornos não contratuais & Erro de expedição do pedido, erros na recepção \\
\hline Retornos comerciais contratuais & Retorno de produtos em consignação \\
\hline Retornos de ajustes de estoques de canal & $\begin{array}{l}\text { Excesso de estoque no canal, baixa rotação do } \\
\text { estoque, introdução de novos produtos, moda ou } \\
\text { sazonalidade. }\end{array}$ \\
\hline Retornos por Garantia/Qualidade & Garantia, defeituoso, danificados \\
\hline Qualidade & Expiração da validade \\
\hline Validade do produto & \\
\hline
\end{tabular}




\begin{tabular}{|l|l|}
\hline Fim de vida & Expiração da utilidade \\
\hline Recall & Manutenção, recolhimento de produtos do mercado \\
\hline
\end{tabular}

Segundo Leite e Brito (2005) os principais destinos dos produtos retornados sem consumo são:

- revenda no mercado primário: Os produtos de retorno devido a ajustes de estoques nos canais de distribuição direta normalmente possuem condições gerais de serem reenviados ao mercado primário, ou seja, o mercado original, com a marca do fabricante e através de redistribuição;

- reparações e consertos: No caso de exigências desta natureza os produtos de retorno serão destinados às reparações necessárias e poderão ser comercializados no mercado primário ou mais freqüentemente no mercado secundário;

- desmanche: O destino de desmanche ocorre quando o bem retornado apresenta-se sem condições de funcionamento para a utilidade de projeto e existe valor de uso em seus componentes. Esta operação é normalmente realizada por empresas que arrematam os produtos nestas condições e os componentes serão enviados ao mercado secundário de peças ou subconjuntos, ou antes, passando por processo de remanufatura;

- remanufatura: O processo de remanufatura se dará quando os componentes do desmanche de bens retornados apresentaram defeitos e devem ser refeitos para ser encaminhado ao mercado secundário. Muitas empresas de grande porte utilizam o sistema de desmontagem de componentes e revisão para alimentar o seu mercado de peças de reposição recuperando valores importantes;

- reciclagem industrial: Os subconjuntos ou partes da estrutura dos bens são comercializados com empresas especializadas na reciclagem dos materiais constituintes destes produtos;

- disposição final: Não havendo nenhuma outra solução de agregar valor de qualquer natureza ao produto retornado ou de suas partes ou materiais, os mesmos são destinados a aterros sanitários ou ao processo de incineração dependendo das peculiaridades de cada país ou região;

- doação: O caso de doações é normalmente um destino de produtos retornados quando existe interesse de fixação de imagem por parte do fabricante e normalmente associado a produtos com certo grau de obsolescência. Caso muito comum no setor de computadores que apresentam vida média útil muito curta, mas que apresentam interesse no mesmo país ou em outros países mais necessitados (LEITE e BRITO, 2005).

Com o pensamento no cliente, as empresas que conseguirem desenvolver e utilizarem a logística reversa de pós-venda como um recurso para atender as necessidades dos clientes podem adquirir ganhos de imagem. A devolução de produtos pós-venda ajuda a desenvolver uma atitude positiva do consumidor com a empresa, possibilitando alcançar a satisfação e assim, desenvolver uma fidelização (KOTLER, 2003).

\section{Satisfação e fidelização}

A satisfação corresponde ao grau em que o consumidor se sente realizado ao julgar quão bem as características de uma oferta proporcionaram ou estão proporcionando prazer relacionado ao consumo. Logo, se o produto ou serviço corresponde suas expectativas, a satisfação acontecerá (OLIVER, 1997).

Embasado nos conceitos de Kotler (2003), entende-se que a satisfação do cliente só acontecerá se suas necessidades quanto a determinado serviço ou produto forem atendidas.

Segundo König e Duarte (2010), a logística reversa vem caminhando rumo à satisfação do cliente através da facilidade de oferecer a eles uma assistência em retornar um produto que esteja com defeito, demonstrando com isso, que a empresa compreende os direitos e desejos de seus clientes. 
Para Kotler e Armstrong (1998), a fidelização de clientes significa criar, manter e acentuar sólidos relacionamentos com os clientes e outros públicos. $\mathrm{O}$ objetivo da fidelização é reter os clientes, evitando que os mesmo migrem para a concorrência e aumentar o valor dos negócios que eles proporcionam (MOUTELLA, 2011). Essa fidelidade ocorre quando a empresa consegue satisfazê-lo completamente, despertando nesses clientes um valor especial a marca.

Leite (2003) expõe que as empresa líderes para se diferenciarem no mercado focam o relacionamento eficaz entre clientes e fornecedores, adequando produtos e processos as necessidades e valores corporativos de seus clientes, permitindo assim duradouros relacionamentos de fidelidade nos negócios.

Conquistar a fidelidade do cliente é, cada vez mais, o desafio de empresas e profissionais, preocupados não só com a sua competitividade, mas com sua própria sobrevivência no mercado. Conseguir fidelizar os consumidores é quase que uma garantia de sobrevivência e bom funcionamento para qualquer empresa, considerando que os clientes fiéis são os mais rentáveis (CARDOSO, 2012).

\subsection{Logística reversa na satisfação e fidelização de clientes}

Para Minahan (1998) a eliminação de produtos e a demanda dos clientes por melhor atendimento estão forçando as empresas a perceber na logística reversa um potencial simultâneo entre a satisfação do cliente e a sua rentabilidade.

Leite (2003), corroborando com os pensamentos de Minahan (1998), o processo da logística reversa faz parte da estratégia de pós-venda, uma vez que determinada empresa lança um produto e coloca em circulação, essa empresa deve estar preparada para eventuais insatisfações por parte dos clientes.

A logística reversa pode ajudar as empresas a alcançar a satisfação de seus clientes através do gerenciamento do fluxo reverso do produto que, se não for executado com eficiência, bem como a existência de alguma dificuldade na devolução dos produtos pode gerar uma grande insatisfação do cliente.

Para Moutella (2011) a satisfação se mede através da relação entre o que o cliente recebeu ou percebeu e o que esperava ter ou ver (percepção $X$ expectativa). Para entender melhor essa expectativa deve-se identificar os critérios segundo quais os clientes avaliam os serviços.

Existem quatro fatores que influenciam as expectativas do consumidor: comunicação boca-aboca; experiência anterior; necessidades pessoais e, comunicações externas (GIANESI E CORRÊA, 1994).

No meio automobilístico, a expectativa do cliente vai além do veículo real. Os clientes buscam durabilidade, segurança e facilidades de manutenção. Logo, a rede de serviço deve ser bem estruturada e capaz de responder rapidamente essa demanda para não perder o cliente, pois o cliente faz uma análise geral da vivência com o serviço.

\section{Modelo de König proposto para a pesquisa}

Neste artigo foi aplicado o modelo de pesquisa de satisfação e fidelização de clientes proposto por König (2012), tendo como base o modelo americano de satisfação de clientes. O propósito da escolha do modelo americano servir como base, se fez por conter informações importantes sobre fidelização e satisfação de clientes, sendo apenas acrescido um novo construto chamado logística reversa de pós-venda. A intenção deste modelo é medir se este construto, através de seus serviços, juntamente com as demais variáveis, contribuem na conquista da satisfação e fidelização dos clientes compradores de automóveis, como pode ser observado na Figura 8. 


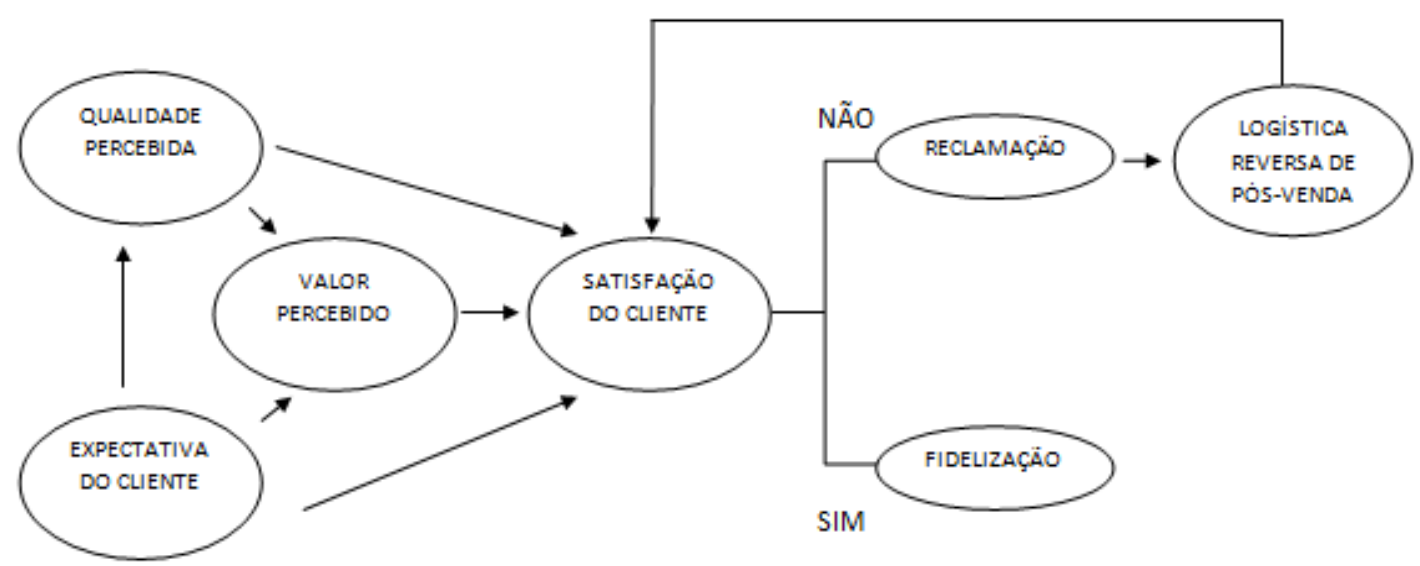

Figura 8 - Modelo de König proposto para a pesquisa

Fonte: Dados da pesquisa (2012)

As variáveis do modelo proposto para a pesquisa são apresentadas a seguir:

- expectativas do cliente: é uma medida influenciada pela experiência do consumo anterior de um determinado produto ou serviço;

- qualidade percebida: é a avaliação do mercado servido de recente experiência de consumo para o cliente;

- valor percebido: é o nível percebido da qualidade do produto em relação ao preço pago pelo cliente;

- satisfação do cliente: é como o cliente sente-se com determinado produto. Esse construto encontra-se no centro do modelo, tendo como antecedentes a qualidade percebida, a expectativas do consumidor e o valor percebido e, como conseqüentes, a reclamação, a fidelidade do consumidor e a logística reversa de pós-venda. Todos esses antecedentes e consequentes passam pela satisfação;

- sim e não da resposta à satisfação dos clientes: são esses dois itens que direcionarão o fluxo. Se o cliente estiver satisfeito, o próximo caminho a seguir pode ser a fidelização. Caso contrário, se sua resposta for não, ele seguirá em direção a reclamação;

- reclamação do cliente: é a atenção dada ao cliente bem como o entendimento dessa reclamação para assim, encaminhar para saná-la;

- logística reversa de pós-venda: são os serviços oferecidos de consertos de defeitos com agilidade e eficiência, de forma consciente, a fim de eliminar a reclamação e ainda, adquirir uma imagem positiva perante aos clientes;

- fidelidade do cliente: é a solução passada ao cliente positivamente, esse se torna fiel.

\subsection{Aplicação do modelo de König no setor automobilístico}

Durante décadas o mercado brasileiro viveu com baixos números de lançamentos onde grandes novidades raramente aconteciam por razões ligadas à instabilidade no país (RAC, 2011).

Atualmente a realidade é outra e o mercado automobilístico brasileiro está crescendo constantemente onde o dinamismo faz com que as montadoras renovem de forma quase que impulsiva seus modelos de veículos para oferecer aos consumidores novidades contínuas e assim, enfrentar a concorrência com mais competência, que reage da mesma forma, fazendo desse mercado uma agitação constante (WEB MOTORS, 2010).

Dados da Federação Nacional da Distribuição de Veículos Automotores (FENABRAVE, 2010) informam que os números do primeiro trimestre de 2010 mostram que o mercado brasileiro segue aquecido como os dois últimos anos e a expectativa para 2011 é que o mercado automobilístico nacional siga crescendo baseado nas condições positivas da economia. E, segundo economistas, nesse mercado ainda existe uma demanda reprimida de novos consumidores, que devem comprar veículos 
zero quilometro aproveitando a expansão da renda, as taxas e prazos atraentes de financiamentos (WEB MOTORS, 2011).

Para Urdan e Zuñiga (2001), com toda essa gama de modelos e a evolução, a diferenciação passa a ser nos serviços de apoio, promovendo a satisfação e a lealdade dos clientes. As Concessionárias de automóveis são as distribuidoras credenciadas pelas montadoras e exclusivas, que são responsáveis pela venda de carros, a comercialização de peças e pela prestação de serviços de pósvenda.

\subsubsection{A escolha da concessionária para este estudo}

A pesquisa foi realizada em uma concessionária de veículos franceses que fica localizada na cidade de Joinville, em Santa Catarina, revendedora de carros importados e nacionais.

A escolha por essa concessionária de automóveis ocorreu por seus produtos serem destinados a atender um público alvo com um nível elevado de exigência, por ter um número menor de clientes no pós-venda comparado as concessionárias de marcas tradicionais, e ainda pela disponibilidade dos responsáveis e todos os envolvidos dessa concessionária em prestar todos os suportes e acompanhamento necessários ao trabalho.

\subsubsection{Metodologia da pesquisa}

Uma pesquisa científica é a realização concreta de uma investigação planejada, desenvolvida e redigida de acordo com as normas da metodologia consagrada pela ciência (RUIZ, 2002).

Para a elaboração deste artigo utilizou-se o tipo de pesquisa de uma pesquisa exploratória que segundo Gil (2002, p. 41) "têm como objetivo proporcionar maior familiaridade com o problema, com vistas de torna-lo mais explícito ou a contribuir hipóteses."

A partir do embasamento teórico adquirido no levantamento bibliográfico, a pesquisadora foi a campo, para verificar no modelo proposto, se existe a contribuição da logística reversa de pós-venda na conquista da satisfação e fidelização de clientes em uma concessionária de automóveis da cidade de Joinville, Santa Catarina. Foi aplicado um questionário que contém 19 perguntas com os clientes da concessionária estudada, no intuito de entrevistar os participantes para o entendimento do objetivo desde estudo. Item este explicado detalhadamente no item método de investigação.

Como classificação de pesquisa de campo, este estudo obteve a classificação quantitativa, pois utilizou a aplicação de questionários, com uma estrutura pré-determinada, objetivando o detalhamento estatístico de seus resultados.

A análise dos dados pesquisados consiste no exame e tabulação para melhor compreender as idéias iniciais da pesquisa. Logo após, o foco analisado são as características agrupadas.

Estas características quantitativas agrupadas são relacionadas por similaridade dentro do contexto da pesquisa, utilizando-se do software Excel para apresentar os dados concentrados. Desta maneira, pode-se observar a relação dos dados no conjunto total pesquisado e então se parte para a conclusão do objetivo deste estudo.

\subsubsection{População e amostra}

Para a aplicação desta pesquisa, o cálculo da seleção da amostra é o proposto por Barbetta (2002), utilizando as fórmulas (1) que trata de uma primeira aproximação do tamanho da amostra. Este será usado se o tamanho da população pesquisada for desconhecido ou muito grande. E (2) que através da primeira aproximação, calcula o tamanho da amostra a ser pesquisada quando a população é conhecida.

$$
n_{0}=\frac{1}{E^{2}}
$$

Onde:

$\mathrm{n}_{0}$ : primeira aproximação do número da amostra;

E²: erro amostral tolerável. 


$$
n=\frac{N . n_{0}}{N+n_{0}}
$$

Onde:

n: tamanho da amostra;

$\mathrm{N}$ : tamanho da população envolvida na pesquisa;

$\mathrm{n}_{0}$ : primeira aproximação do número da amostra.

Dados obtidos por funcionários e ex-funcionários das concessionárias de diversas marcas de automóveis existentes em Joinville/SC, nas quais também vendem veículos de passeio, tratadas como concessionárias A, B, C, D e E, conforme mostra a Tabela 2, dão suporte para obter informações do tamanho da amostra da concessionária pesquisada neste estudo.

Tabela 2 - Número de atendimento mensal das concessionárias

\begin{tabular}{|l|c|}
\hline \multicolumn{1}{|c|}{ Concessionárias } & Total de Atendimentos \\
\hline Concessionária A & 1860 \\
\hline Concessionária B & 1500 \\
\hline Concessionária C & 900 \\
\hline Concessionária D & 3000 \\
\hline Concessionária E (pesquisada) & 750 \\
\hline
\end{tabular}

Fonte: Dados das concessionárias (2012)

Sendo assim, ao considerar que a concessionária pesquisada registra um movimento mensal de 750 clientes, conforme aponta a Tabela 2, procedeu-se ao cálculo para definir a amostra.

Com as fórmulas descritas acima, considerando uma margem de erro tolerável de $10 \%$ e uma população de 750 clientes mensais, obteve-se o resultado da amostra de 88 clientes que serão entrevistados aleatoriamente, conforme utilizem os serviços de pós-venda da concessionária avaliada.

\subsubsection{Método de investigação}

A pesquisa utilizou como instrumento de coleta de dados, um questionário fundamentado no modelo proposto por König (2012). Esse foi organizado para avaliar a contribuição da logística reversa de pós-venda na satisfação e fidelização de clientes. O questionário foi composto por duas partes - a primeira, com questões enumeradas de E1 (expectativa) a F19 (fidelização), utilizando as variáveis do modelo proposto para a pesquisa e, a segunda parte composta por perguntas sobre o perfil do cliente. As variáveis pesquisadas foram:

- expectativa: avaliação da expectativa perante o agendamento de serviços (E1), aos serviços prestados pela concessionária no veículo (E2), ao atendimento dos funcionários da concessionária (E3);

- qualidade percebida: avaliação da qualidade percebida perante as instalações da concessionária bem como organização, conforto e limpeza (Q4), ao grau de confiança pela concessionária nos serviços executados no veículo (Q5), ao cumprimento do prazo de entrega do veículo passado pela concessionária (Q6);

- valor percebido: avaliação do valor percebido quanto ao preço pago pelos serviços efetuado no veículo (V7), quanto ao profissionalismo da concessionária pelos serviços prestados (V8);

- satisfação: avaliação da satisfação ao atendimento da concessionária (S9), com os serviços executados no veículo (S10);

- reclamação: avaliação da reclamação referente aos serviços efetuados com pouca qualidade (R11), referente ao defeito voltar a apresentar problema (R12), quanto a aparecer um novo defeito (R13);

- logística reversa: avaliação da logística reversa quanto eficiência e agilidade no conserto das peças (L14), quanto a remanufatura ou conserto das peças (L15), quanto a destinação correta das peças substituída (L16); 
- fidelização: avaliação da fidelização perante a possibilidade em adotar os procedimentos da logística reversa pela concessionária (F17), em comprar outro veículo da marca (F18), em recomendar a concessionária (F19).

\subsection{Análise e discussão dos resultados da aplicação do modelo de König no setor automobilístico}

Como primeiro levantamento dos dados da pesquisa, optou-se em realizar a análise da segunda parte do questionário onde constam as informações do perfil do cliente, bem como sexo, idade e escolaridade, por ter uma visão clara do perfil dos respondentes. Logo após, segue o levantamento das 19 perguntas fechadas do questionário separadamente para análise.

\subsubsection{Expectativa}

O objetivo deste indicador foi analisar se os serviços oferecidos pela concessionária eram o que os clientes esperavam receber.

Através deste levantamento foi possível diagnosticar que a expectativa do cliente em relação ao agendamento para a efetivação de serviços, representada pela questão E1 é de $95 \%$ entre bom e excelente, conforme ilustrado na Figura 9.

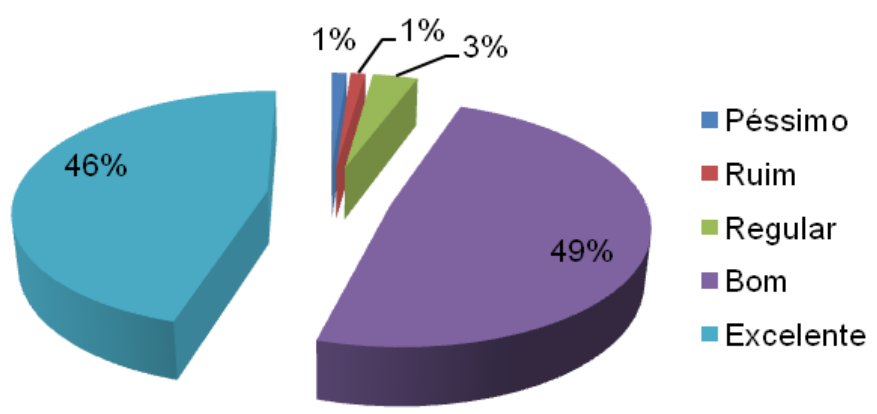

Figura 9 - Agendamento de serviços (E1)

A maior parte dos respondentes assinalou estas opções devido a concessionária trabalhar com uma margem de três dias, no máximo, para a efetuação de serviços, a partir da data de contato do cliente.

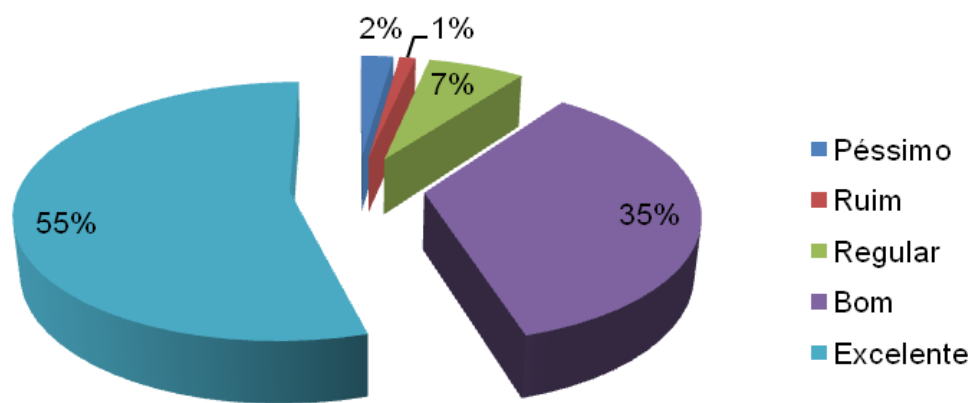

Figura 10 - Serviços prestados pela concessionária no veículo (E2)

Quanto à expectativa do cliente em relação aos serviços prestados pela concessionária no veículo, questão E2 que está ilustrada na Figura 10, percebe-se que 35\% dos pesquisados responderam ser bom e 55\% responderam excelente.

A concessionária segue todas as recomendações de serviços passados pela montadora para assim, possa prestar bom serviço no automóvel do cliente.

$\mathrm{Na}$ Figura 11, foi possível analisar que a expectativa dos clientes em relação ao atendimento dos funcionários da concessionária, questão E3 do questionário, está entre excelente e bom com 97\%, sendo que $3 \%$ assinalaram regular. 


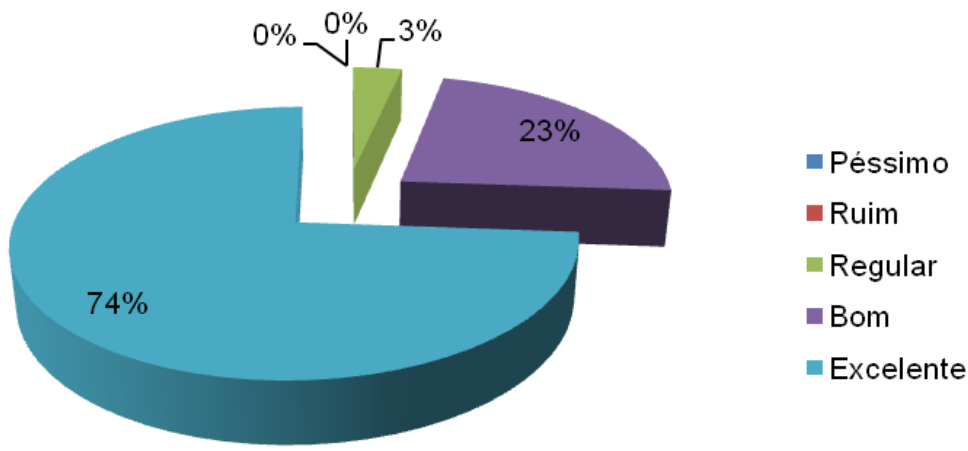

Figura 11 - Atendimento dos funcionários da concessionária (E3)

A maioria dos respondentes escolheu entre bom e excelente, pois a concessionária investe em treinamentos constantes dos funcionários com base em atender bem os clientes.

\subsubsection{Qualidade percebida}

O objetivo deste item está em analisar a percepção do cliente quanto à customização e confiabilidade na concessionária na qual ele é cliente.

A percepção dos clientes quanto à qualidade das instalações da concessionária, bem como a organização, conforto e limpeza, questão Q4 do questionário. Constatou-se que $99 \%$ dos pesquisados consideram entre bom e excelente, ficando o $1 \%$ com a resposta regular.

Estas respostas tiveram tal peso devido a concessionária ter uma equipe de limpeza, por ter um espaço com café, televisão, revistas e jornais atualizados sempre a disposição do cliente.

A pergunta na qual questiona a percepção dos clientes com o grau de confiança em relação à concessionária aos serviços executados no veículo da questão Q5, atingiu o resultado de $60 \%$ excelente e $31 \%$. Esse resultado se faz em função das explicações detalhadas dos serviços realizados no veículo passada pelos funcionários ao cliente.

Foi possível fazer uma análise dos pesquisados quanto a qualidade percebida sobre o cumprimento do prazo de entrega do veículo passado pela concessionária através da questão Q6. Observou-se que $92 \%$ dos pesquisados optaram por responder ente bom e excelente.

O atingimento deste número é possível devido a concessionária, para alguns serviços, já tem o tempo padrão de reparo, facilitando assim o cumprimento do prazo de entrega estipulado por ela.

\subsubsection{Valor percebido}

Avaliar a percepção do cliente quanto à qualidade percebida no serviço com o preço pago é o objetivo desta etapa. Através desta análise foi possível diagnosticar que o valor percebido do cliente quanto ao preço pago pelos serviços efetuado no veículo, questão V7, diferente dos resultados anteriores, dos oitenta e oito respondentes, $20 \%$ avaliam como sendo regular, $26 \%$ como excelente e $51 \%$ como bom, conforme ilustra a Figura 12.

A concessionária trabalha com tabelas de preços de serviço baseando-se numa média estipulada pela fábrica.

Na questão V8, pôde-se analisar que o valor percebido dos clientes com o profissionalismo da concessionária nos serviços prestados com o preço pago é de $60 \%$ excelente e $33 \%$ bom.

Além de a concessionária investir em treinamentos de atendimento a clientes, conforme citado na questão E3, ela investe em cursos passados pela montadora com base nos conhecimentos de serviços prestados por ela. 


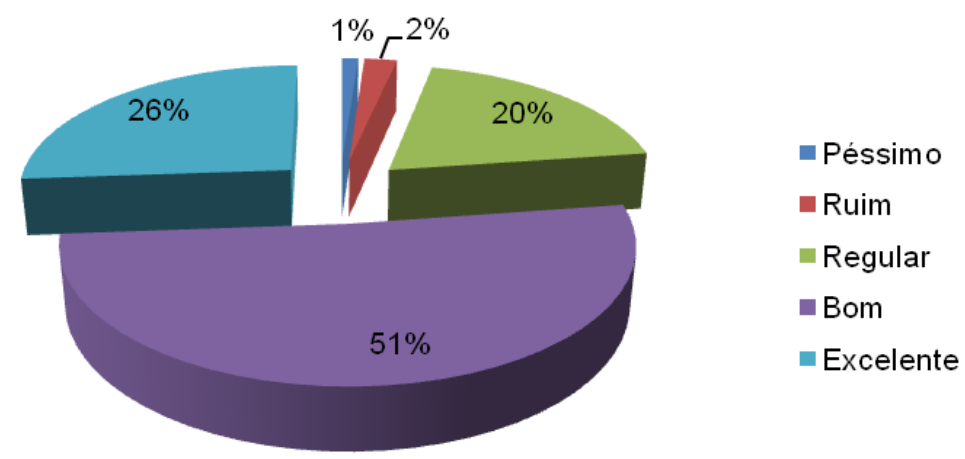

Figura 12 - Preço pago pelos serviços efetuados no veículo (V7)

\subsubsection{Satisfação}

$\mathrm{O}$ item satisfação tem como interesse analisar se as necessidades dos clientes pesquisados foram satisfeitas pela concessionária. No levantamento feito na questão S9, referente à satisfação do cliente com a concessionária foi verificado que $93 \%$ dos clientes responderam entre excelente e bom que está ilustrado na Figura 13.

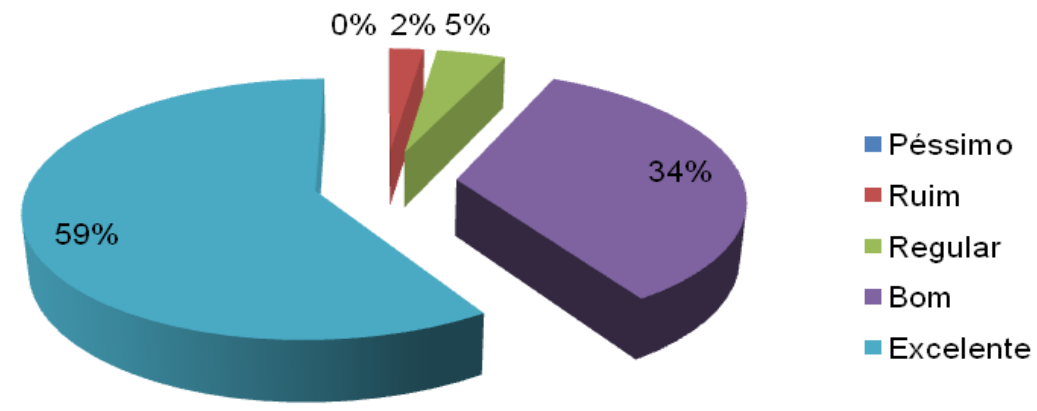

Figura 13 - Satisfação com a concessionária (S9)

A maior parte dos pesquisados escolheram estas respostas, pois a concessionária prioriza o atendimento a clientes, buscando suprir suas necessidades com o auxilio de funcionários comprometidos.

No que diz respeito à satisfação em relação aos serviços executados no veículo, questão $\mathrm{S} 10$, dos oitenta e oito respondentes, $88 \%$ consideram entre excelente e bom. A maior parte dos respondentes afirma que os serviços executados pela concessionária satisfazem suas necessidades, devido ao investimento da concessionária em cursos oferecidos aos funcionários, conforme citado anteriormente, ampliando seus conhecimentos e tornando-os aptos a executar os serviços solicitados pelos clientes.

\subsubsection{Reclamação}

Este item teve como objetivo analisar o comportamento do cliente perante a uma possível situação insatisfatória em seu veículo. O levantamento informa que $74 \%$ dos oitenta e oito pesquisados consideram péssima a possibilidade dos serviços solicitados a ser executado serem realizados com pouca qualidade, da questão R11.

Através do levantamento feito sobre o item reclamação, avaliou-se que para os clientes, se o defeito solicitado para conserto voltar a apresentar problema, da questão R12, 60\% dos pesquisados afirmam ser péssimo, $22 \%$ ruim e $17 \%$ regular.

Já quanto a aparecer um novo defeito no veículo, pergunta R13, 35\% dos respondentes acham regular, $34 \%$ respondeu ruim e, $25 \%$ consideram péssimo. 


\title{
5.2.9 Logística reversa de pós-venda
}

O objetivo deste indicador estava em analisar a importância que os clientes percebem nos processos logísticos reversos de pós-venda, uma vez que a concessionária, até então, não se utiliza de todos os serviços. Com este levantamento, foi possível diagnosticar que $96 \%$ dos pesquisados consideram entre excelente e bom se o veículo ao apresentar qualquer tipo de defeito, dentro ou fora da garantia ou recall, as peças danificadas fossem consertadas com agilidade e eficiência. A concessionária, na maioria das vezes, substitui as peças nas quais apresentam defeito.

No levantamento feito da questão L15, referente às respostas da avaliação dos clientes sobre as peças substituídas do veículo se estas fossem remanufaturadas ou consertadas e devolvidas ao mercado secundário tiveram variações. Dos oitenta e oito clientes pesquisados, $43 \%$ consideraram péssimo e ruim, $39 \%$ bom e excelente e, $18 \%$ regular. Ao substituir determinada peça do automóvel que se encontra com defeito, a concessionária pesquisada encaminha para a sucata.

Quanto ao levantamento efetuado referente a preocupação na destinação correta das peças substituídas do veículo, questão L16 do questionário, demonstra que 92\% dos clientes consideram entre bom e excelente a sua avaliação na preocupação.

\subsubsection{Fidelização}

O objetivo desta etapa foi analisar se a concessionária atingiu a confiança dos clientes com os serviços executados demonstrados nos itens anteriores e principalmente, analisar o quanto representou o indicador "logística reversa de pós-venda" para os clientes pesquisados.

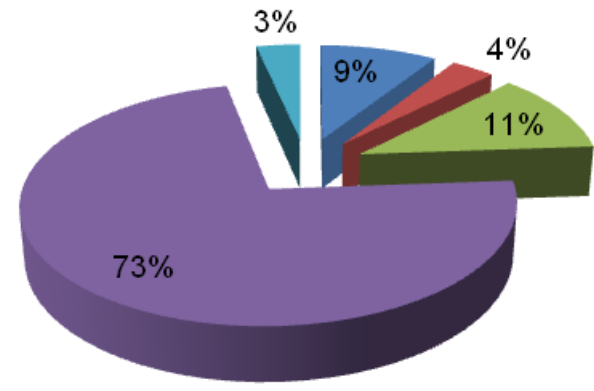

\author{
- Muito provavelmente não \\ - Provavelmente não \\ - Talvez sim talvez não \\ - Certamente sim \\ - Não sei
}

Figura 14 - Adoção dos processos logísticos reversos de pós-venda na concessionária (L14, L15 e L16) considerar-se-ia satisfeito com a marca (F17)

Através deste levantamento foi possível diagnosticar que a possibilidade dos pesquisados em considerarem satisfeitos em relação à concessionária adotar os processos da logística reversa de pósvenda aos seus serviços, representada pela questão F17 do questionário e representada pela Figura 14, observou-se que $73 \%$ dos oitenta e oito respondentes assinalaram que certamente sim.

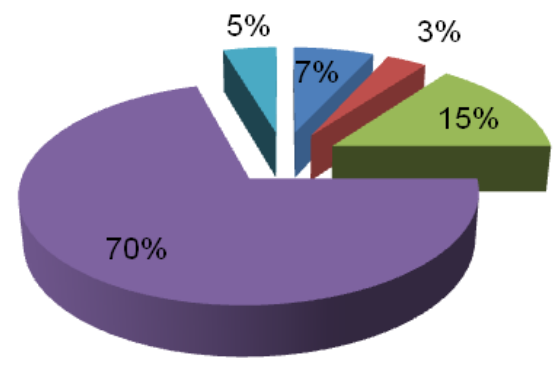

$$
\begin{aligned}
& \text { - Muito provavelmente } \\
& \text { não } \\
& \text { - Provavelmente não } \\
& \text { - Talvez sim talvez não } \\
& \text { - Certamente sim } \\
& \text { - Não sei }
\end{aligned}
$$

Figura 15 - Relação de serviços executados com a compra de outro veículo da marca (F18)

O levantamento feito em relação aos serviços efetuados no veículo se os pesquisados comprariam outro automóvel da marca, questão $\mathrm{F} 18,70 \%$ dos respondentes afirmaram que certamente sim, conforme Figura 15. 
A questão F19 ilustrada pela Figura 16, realizou-se o levantamento referente se o cliente recomendaria a concessionária levando em consideração os serviços prestados.

Dos oitenta e oito respondentes do questionário aplicado, $77 \%$ alegaram que certamente sim, recomendariam a concessionária estudada.

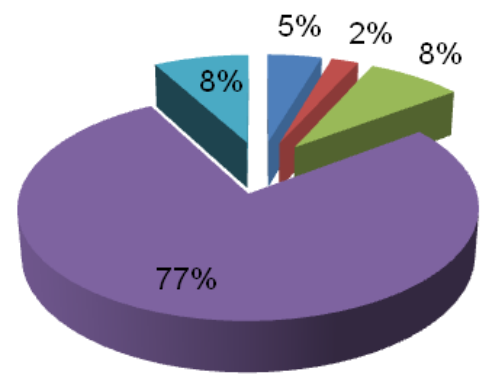

\author{
- Muito provavelmente \\ não \\ - Provavelmente não \\ - Talvez sim talvez não \\ - Certamente sim \\ - Não sei
}

Figura 16 - Relação de serviços prestados com a recomendação da concessionária (F19)

\title{
5.3 Conclusão da análise
}

Após a análise e discussão dos resultados da aplicação do modelo de König no setor automobilístico, fez-se necessário unir as informações de cada variável para perceber a relação entre expectativas do cliente, qualidade e valor percebido, satisfação do cliente e logística reversa de pósvenda.

O número dos entrevistados para a análise desta pesquisa obteve resultado significativo por ter atingido, conforme planejamento, o número de 88 questionários de amostragem de acordo com a população. As variáveis sócio-econômicas analisadas foram: sexo, faixa etária e nível de escolaridade. Pode-se concluir que a maior parte dos clientes da concessionária que responderam ao questionário, conforme mostra a Tabela 3, são do sexo masculino, com faixa etária entre 31 a 40 anos e com o nível de escolaridade de $3^{\circ}$ grau ou mais.

Tabela 3- Variáveis sócio-econômicas

\begin{tabular}{ccc}
\hline Sexo & Faixa etária & Escolaridade \\
\hline Masculino (78\%) & 31 a 40 anos $(26 \%)$ & $3{ }^{\circ} \mathrm{Grau}$ ou mais $(73 \%)$ \\
\hline
\end{tabular}

Fonte: Dados da pesquisa (2012)

$\mathrm{Na}$ Tabela 4 está ilustrada a análise acumulativa das variáveis expectativas, qualidade percebida e valor percebido dos clientes da concessionária. Percebe-se que as variáveis expectativas e qualidade percebida possuem peso significativo na variável satisfação.

Tabela 4 - Variáveis antecedentes a satisfação

\begin{tabular}{ccc}
\hline Expectativa & Qualidade percebida & Valor percebido \\
\hline Bom e excelente (94\%) & Bom e excelente (93\%) & Bom e excelente (85\%) \\
\hline & Fonte: Dados da pesquisa (2012) &
\end{tabular}

De acordo com Eckes (2001) os clientes satisfeitos e fiéis são menos sensíveis a preços e mais propensos a investir seu dinheiro em produtos ou serviços de maior qualidade. A pesquisa realizada mostrou não estar totalmente de acordo com o conceito de Eckes (2001). O resultado da variável valor percebido constata que os pesquisados não estão totalmente de acordo com o preço pago pelos serviços disponibilizados pela concessionária. Embora esse resultado não tenha obtido o mesmo peso do que a variável expectativa do cliente e qualidade percebida sobre o construto satisfação, mesmo assim baixou o resultado final da variável satisfação.

Observou-se que $91 \%$ dos clientes de pós-venda da concessionária consideram-se estar satisfeitos com os serviços prestados. Kotler (2003) enfatiza que a satisfação do cliente só acontecerá se suas necessidades quanto a determinado serviço forem atendidas. Logo, pode-se afirmar que as 
necessidades dos clientes pesquisados foram atendidas e eles estão satisfeitos com os serviços prestados.

Conforme observado nesse estudo, fazendo uma análise da satisfação com a fidelização dos clientes pesquisados, $91 \%$ dos clientes consideram-se satisfeitos e $74 \%$ são considerados fiéis. Essa discrepância pode ter obtido influência da opção disposta aos clientes na resposta de fidelização do questionário, por constar somente uma resposta afirmativa e as demais, duas negativas e duas indecisas. Essa discrepância dos resultados pode ter obtido influência da opção exposta aos clientes na resposta de fidelização do questionário, por constar somente uma resposta afirmativa e as demais, duas negativas e duas indecisas.

Moutella (2011) e Kotler (2003) concordam em que se as necessidades dos clientes forem além de suas expectativas, esse cliente ficará encantado, ou seja, satisfeito e possivelmente será um cliente fiel. E essa fidelidade ocorre quando a empresa consegue satisfazê-los completamente. Logo, através dos resultados da pesquisa referente à variável satisfação e dos estudos de Moutella (2011) e Kotler (2003) concluiu-se que os clientes satisfeitos da concessionária são considerados clientes fidelizados.

Pode-se constatar que a avaliação acumulada dos clientes quanto aos questionamentos referente à variável reclamação, no que diz respeito aos defeitos que possam ocorrer no veículo, obteve um peso significativo e esperado. Os pesquisados não toleram a hipótese dos serviços serem executados com pouca qualidade ou o problema que foi solicitado um reparo voltar a acontecer. Já a hipótese de aparecer um novo defeito ao veículo é um pouco tolerável por eles, levando em consideração que o automóvel é uma máquina na qual pode ocorrer defeito.

O resultado acumulativo da avaliação feita dos clientes da concessionária sobre os serviços da logística reversa de pós-venda. Observar que $76 \%$ dos clientes consideram os serviços logísticos reversos entre bom e excelente.

Esse resultado não obteve um nível ainda mais alto devido aos respondentes terem rejeição ao fato da concessionária remanufaturar ou consertar a peça danificada substituídas do seu veículo e encaminhá-la ao mercado secundário.

Para os autores Dornier et al. (2007) e Figueiredo et al. (2006), os serviços da logística reversa de pós-venda é um dos mais valorizados pelos clientes, mais especificamente, na habilidade de resolver os problemas que os clientes possam vir a ter com o produto adquirido e com o fator meio ambiente. O produto com defeito, independentemente qual seja o motivo, deve ter seu valor recuperado e um tratamento adequado, pois pode trazer ganhos ou perdas da imagem da empresa (Guarnieri et al., 2006).

Ao avaliar o resultado referente aos clientes ficarem satisfeitos com a possibilidade da concessionária adotar os serviços da logística reversa de pós-venda, mesmo com a não aprovação de muitos entrevistados quanto à remanufatura ou conserto, é de $73 \%$ da amostra.

Para Leite (2003), a logística reversa através de seus serviços no pós-venda é um dos meios utilizados para ter um relacionamento duradouro e ter uma garantia de fidelização de clientes.

O levantamento acumulativo quanto à fidelização dos clientes da concessionária obteve um resultado significativo. Muitas pessoas da amostra responderam que certamente comprariam outro veículo da marca e ainda, recomendaria esta concessionária pra outras pessoas. Um detalhe de mera importância e vale ressaltar que novamente, levanta-se a hipótese de que o número de porcentagem que se refere à resposta certamente sim só não obteve um resultado maior devido à opção exposta aos respondentes. Contudo, pode-se concluir que $74 \%$ dos oitenta e oito respondentes são clientes fiéis a concessionária. 


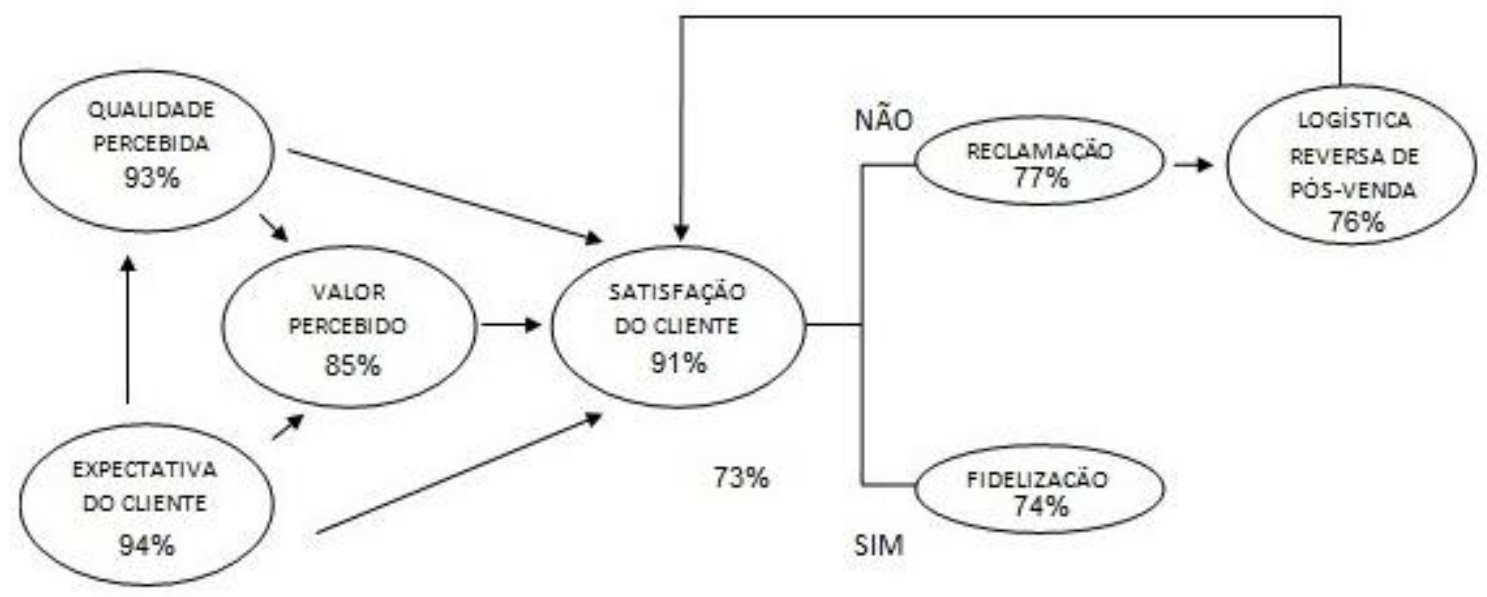

Figura 17 - Modelo proposto para o estudo e seus resultados Fonte: Dados da pesquisa (2012)

O objetivo da fidelização de clientes para Kotler e Armstrong (1998) e também para o autor Moutella (2011) é reter os clientes, evitando que os mesmos migrem para a concorrência. Custa mais caro conquistar um novo cliente do que reter um cliente atual e, atender as necessidades do cliente atual pode ser mais fácil, porque se pode saber melhor quem são, onde estão e quais suas necessidades (KOTLER, 2003). A Figura 17 ilustra a conclusão da pesquisa no modelo proposto para este estudo com os devidos resultados, citados anteriormente, em cada construto analisado na pesquisa.

\section{Conclusões}

O objetivo principal desta pesquisa foi apresentar o modelo de satisfação e fidelização de clientes desenvolvido por König (2012) que pretendeu, através de práticas da logística reversa de pósvenda aplicados em uma concessionária de veículos em Joinville, SC, contribuir na busca pela fidelização de clientes.

Com o modelo formulado e os resultados apresentados, considera-se que este objetivo foi atingido satisfatoriamente, pois foi possível identificar que os clientes da concessionária percebem na logística reversa de pós-venda um diferencial para eliminar a reclamação e assim, tornar-se satisfeitos e fidelizados a marca. Logo, conclui-se que a logística reversa através de seus serviços, bem como a preocupação com a destinação correta e reutilização dos produtos, possibilita com que os clientes atinjam uma visão de diferenciação da empresa e, com isso, a empresa obtém uma vantagem competitiva em relação aos seus concorrentes conseguindo então satisfazer e fidelizar seus clientes.

O mercado automobilístico está cada vez mais concorrido e a disputa por clientes cada vez mais acirrada. Neste contexto, faz-se necessário buscar meios que promovam vantagem competitiva e a satisfação e fidelização de clientes. Pode-se concluir, finalmente, que a logística reversa de pósvenda foi capaz de contribuir na conquista da satisfação e fidelização de clientes. Pode-se concluir também que a utilização dos serviços da logística reversa de pós-venda transmite uma vantagem competitiva para as empresas por tratar a reclamação do cliente de maneira eficiente, e ainda por efetuar a destinação correta das peças defeituosas.

\section{Referências}

BALLOU, R. H. Gerenciamento da cadeia de suprimentos: logística empresarial. Ed. 5. Porto Alegre, Bookman, 2006.

BARbetTA, P. A. Estatística Aplicada as Ciências Sociais. Ed. 5. São Paulo: Editora Atlas, 2002. 
CARDOSO, C. Fidelização de clientes. Disponível em: <http://www2.informazione.com.br/cms/opencms//desafio21/artigos/variedades/artigosprincipais/0079 .html>. Acesso em: 10 jan. 2012.

COTTRILL, K. Return to send. Traffic World, vol. 262 (7): p. 17-18, 2000.

DORNIER, P. P.; ENERST, R.; FENDER, M.; KOUVELIS, P. Logística e operações globais: Texto e Casos. Ed. 1. São Paulo: Atlas, 2007.

DROHOMERETSKI, E.; SUETAKE, G. Y. Análise de viabilidade na utilização de embalagens descartáveis para distribuição de produtos hidropônicos: um estudo de caso. In: CONGRESSO INTERNACIONAL DE ADMINISTRAÇÃO. Ponta Grossa, PR, 2008.

ECKES, G. A. A revolução seis sigma: o método que levou a GE e outras empresas a transformar processos em lucro. Rio de Janeiro: Campus, 2001.

FENABRAVE. Mercado. Disponível em: <http://www.fenabrave.org.br/principal/pub/anexos/20100909024501semestral_2010.pdf> Acesso em: 25 mai. 2011.

FIGUEIREDO, K. F.; FLEURY, F. P.; WANKE, P. Logística e gerenciamento da cadeia de suprimentos: Planejamento do fluxo de produtos e dos recursos. 1. ed. São Paulo: Atlas, 2006.

GIANESI, I. G. N.; CORRÊA, H. L. Administração estratégica de serviços. São Paulo: Editora Atlas, 1994.

GIL, Antônio Carlos. Como elaborar projetos de pesquisa. 4 ed. São Paulo: Atlas, 2002.

GUARNIERI, P.; CHRUSCIACK, D.; OLIVEIRA, I.; HATAKEYAMA, K.; SCANDELARI, L. Warehouse Management System: adaptação proposta para o gerenciamento da logística reversa. Revista Produção, v. 16, n.1, p. 126-139. Jan/Abr, 2006.

JOHNSON, M. D.; GUSTAFSSON, A.; ANDREASSEN, T. W.; LERVIK, L.; CHA, J. The evolution and future of national customer satisfaction index models. Journal of Economic Psychology, 2001, v. 22, p. $217-245$.

KÖNIG, T. C.; DUARTE, P. C. Logística reversa de pós-venda como uma ferramenta para a satisfação. In: CONGRESSO DE ENGENHARIA DE PRODUÇÃO DA REGIÃO SUL, Joinville. Santa Catarina, 2010, 1 CD.

KÖNIG, T. C. A contribuição da logística reversa de pós-vendas na conquista da satisfação e fidelização de clientes: um estudo de caso no setor automobilístico. Dissertação de Mestrado. Programa de Pós-Graduação em Engenharia de Produção. Joinville. IST/SOCIESC, 2012, 93 p.

KOTLER, P. Administração de marketing: a edição do novo milênio. 10. Ed. São Paulo: Prentice Hall, 2003.

KOTLER, P.; ARMSTRONG, G. Princípios de marketing. 7. ed. Rio de Janeiro: Prentice-Hall do Brasil, 1998.

LACERDA, L. Logística reversa: uma visão sobre os conceitos básicos e as práticas operacionais. Sargas competência em logística, 2009.

LEITE, P. R. Logística reversa: meio ambiente e competitividade. São Paulo: Pearson Prentice Hall, 2003.

LEITE, P. R.; BRITO, E. Logística Reversa de Produtos não consumidos: uma descrição das práticas das empresas atuando no Brasil. Revista Eletrônica de Gestão Organizacional, Vol.3, nº.3, set/dez 2005.

LIRA, J. Fatores que afetam a satisfação e a fidelização do cliente: Um estudo com compradores de automóveis. Dissertação de mestrado em Engenharia de Produção, UFRN, 2003.

MINAHAN, T. Manufacturers take aim at end of the supply chain. Purchasing,1998. 
MOUTELLA, C. Fidelização de clientes como diferencial competitivo. Disponível em: $<$ http://www.portaldomarketing.com.br/Artigos/Fidelizacao\%20de\%20clientes\%20como\%20diferenci al\%20competitivo.htm>. Acesso em: 05 jul. 2011.

NOVAES, A. G. Logística e gerenciamento da cadeia de distribuição: estratégia, operação e avaliação. Ed 3. Rio de Janeiro: Elsevier, 2007.

OLIVER, R. L. Satisfaction: a behavioral perspective on the consumer. $2^{\text {nd }}$. ed., 1997.

RAC. Mercado automobilístico tem boom de lançamentos. Disponível em: $<$ http://www.rac.com.br/noticias/economia/79830/2011/04/05/mercado-automobilistico-tem-boom-delancamentos.html>. Acesso em: 07 jul. 2011.

RODRIGUES, J. M. S. Gestão da satisfação e da fidelização de consumidores: um estudo dos fatores que afetam a satisfação e a fidelização no mercado de turismo. UFRN, 2003.

ROGERS, D. S.; TIBBEN, L. Reverse Logistics Trends and Practices. Reno, University of Nevada: 1998.

RUIZ, J. A. Metodologia Científica. Ed.5. São Paulo: Atlas, 2002.

URDAN, A. T.; ZUÑIGA, M. K. H. Satisfação com assistência técnica e lealdade ao fabricante no ramo automobilístico. RAE, São Paulo, 2001.

WEB MOTORS. Mercado brasileiro teve 307 novidades em 2010. Disponível em: <http://www.webmotors.com.br/wmpublicador/Colunista2_conteudo.vxlpub?hnid=45086>. Acesso em: 07 jul. 2011.

WEB MOTORS. Mercado brasileiro registra recorde histórico de vendas no primeiro trimestre de 2011.

<http://www.webmotors.com.br/wmpublicador/Mercado_Conteudo.vxlpub?hnid=45346>. Acesso em: 07 jul. 2011.

WHITELEY, R. C. A empresa totalmente voltada para o cliente: do planejamento à ação. Rio de Janeiro: Campus, 1996. 